\title{
Natural Pozzolan as a Partial Substitute for Cement in Concrete
}

\author{
Ghassan K. Al-Chaar ${ }^{1, *}$, Mouin Alkadi ${ }^{2}$ and Panagiotis G. Asteris ${ }^{3}$ \\ ${ }^{I}$ Research and Development Center (ERDC), Construction Engineering Research Laboratory, Champaign, IL, USA; \\ ${ }^{2}$ Techno Advanced Building Material Company. Damascus Road, Sweda, Syria $;{ }^{3}$ Computational Mechanics Laboratory, \\ School of Pedagogical and Technological Education, 14124 Heraklion, Athens, Greece
}

\begin{abstract}
In this paper, the use of natural pozzolan as a partial cement substitute in concrete materials is investigated. By means of a test series, four mixes using three types of natural pozzolan, as well as a Class F fly ash, are evaluated. The effectiveness of each pozzolan in controlling alkali-silica reactions has been studied. Correlations have been revealed between the mechanical properties of the proposed mixes and a Portland cement control mix. The results are also compared with industry standards for mortars made with fly ash and silica fume. The paper's findings indicate that one type of pozzolan may be used as a substitute for fly ash, but not for silica fume.
\end{abstract}

Keywords: Natural pozzolan, cement replacement, concrete, mortar, fly ash, mechanical properties, silica fume.

\section{INTRODUCTION}

Under the strong contemporary demand for modern and environmentally friendly materials, natural pozzolan can be proved to be such a material and several researchers have focused their research efforts in using it as a partial substitute in the manufacture of concrete and mortar [1-10].

Pozzolans are divided into two categories, namely the natural and the artificial, as metakaoline and silica fume (SF). In recent years, the industry has shifted to using natural pozzolans because of their lower cost and accessibility. A pozzolan is a siliceous material that can be used as an inexpensive substitute for cement in mortar mixtures. Pozzolans participate in a cementitious reaction with calcium hydroxide (i.e., lime) and other alkalis. Pozzolans are effective at lowering the mortar's heat of hydration, which improves its workability and durability. They can also improve concrete and mortar resistance to both sulfate attack and the alkalisilica reaction (ASR), which makes it beneficial to use in large concrete projects such as bridges and dams (Gibbons 1997 [11], Tsimas et al. 2005 [12], Hossain and Mol 2011 [8]), as well as in the restoration of historic and monumental masonry structures as a restoration mortar (Moropoulou et al. 1998 [13], 2004 [14] and 2005 [15], Asteris et al. 2005 [16]).

Major sources of natural and manmade pozzolans include volcanic mineral deposits, fired and crushed clay, and fly ash, which is created during the burning of coal for power generation (Gibbons 1997 [11]). Most pozzolans are profuse, but current uses for them are limited. Consequently, they represent a potential source of inexpensive construction material.

\footnotetext{
*Address correspondence to this author at the Construction Engineering Research Laboratory, Champaign, IL, USA;

Tel: 217-373-7247; Fax: 217-722-3320;

E-mail: ghassanalchaar@yahoo.com
}

This paper investigates the feasibility and effectiveness of using naturally occurring pozzolan materials as an additive or substitute for cement in concrete mixtures. This investigation has been carried out through a series of experiments using a Class F fly ash and three types of natural pozzolans under the following laboratory tests: chemical composition, moisture content, loss on ignition, compressive strength, strength activity index, expansion from alkali-silica reaction (ASR), heat of hydration, slump, drying shrinkage, and autoclave expansion.

\section{LITERATURE REVIEW}

Alkalis in cement (typically calcium hydroxide and sodium and potassium oxide) can react with aggregates containing reactive silica or carbonate mineral constituents. In cured cement, these reactions produce different types of expansion that can cause concrete deterioration through internal cracking, surface cracking, and/or aggregate pop-out (Dolar-Mantuani 1983 [17]). Classic research by Stanton (1940) [18] ascribed ASR degradation to an expansive chemical reaction between the alkalis contained in the cement paste and certain reactive forms of silica within aggregate. Stanton identified opal and chert as common forms of reactive silica.

Pozzolans as an additive reduce cracking and expansion that results from ASR. The ASR is known to be normally occurs from the following combination of conditions (Hobbs 1988 [19]):

1. significant quantity of reactive silica.

2. reactive silica within a critical range of proportions.

3. available alkalis above a critical level.

4. water from an external source.

Suitable precautions must be taken to minimize or eliminate harmful expansion and cracking, such as:

- decreasing the amount of reactive aggregate (Björk $2002[20])$. 
- using low-alkali cement as per ASTM C150-09 [21].

- using mineral admixtures such as pozzolans or blast furnace slag (Lane et al. [22]; Wang and Gillott 1993 [23]; Thomas and Innis 1998 [24]).

- reducing the availability of water such that the relative humidity in concrete pores falls below about 85$90 \%$.

In mass and high-strength concrete, the production of heat during the hydration reaction creates thermal gradients which can induce cracking in hardening concrete (Yeon et al. 2012 [25], De Schutter 2002 [26]). Thermal cracking can be mitigated by reducing the heat of hydration, a goal which can be achieved through the use of pozzolans or ground, granulated blast furnace slag (Tokyay et al. 2012 [27], Nili and Salehi 2010 [28]).

\section{CHARACTERISTICS OF CONCRETE FORMU- LATED WITH POZZOLAN ADDITIVES}

\subsection{Concrete Formulation Components}

\subsubsection{Cementitious Materials}

For this investigation, pozzolanic materials were selected which conformed to ASTM C618-00 [29]. Natural pozzolan was used from Saudi Arabia (Pozzolan S1), South Africa (Pozzolan S2), and Jordan (Pozzolan J). This phase of testing also included a Class F fly ash, whose properties are specified in ASTM C618-00 [29].

The natural pozzolan samples were crushed, ground, and tested. A Cilas Granulometre 715 device was used to determine the grain size distributions of the materials. Type I Portland cement was used in the production of concrete mixes. Chemical properties of the cement were tested periodically in the laboratory. (Table 1) shows chemical composition, loss on ignition, density, and fineness of all cementi- tious materials, while (Fig. 1) shows their particle size distributions.

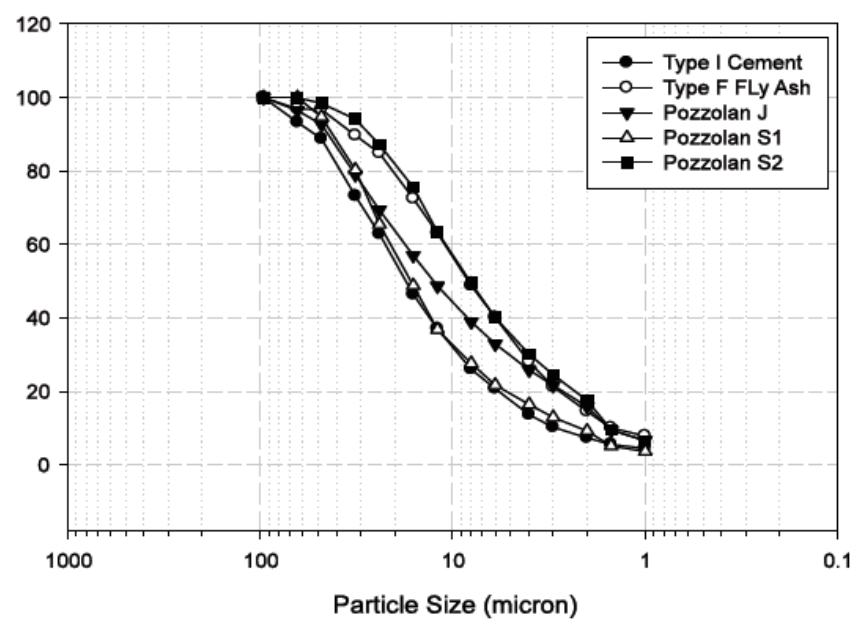

Fig. (1). Particle size distribution of cementitious materials.

\subsubsection{Aggregate Materials}

Washed, surface-dry basalt aggregates were used in this study. Fine aggregate, consisting of crushed basalt rocks, was sifted, washed over a \#100 $(150 \mu \mathrm{m})$ sieve with a water spray, and re-graded to the final, desirable particle size distribution. Grain size distributions for all aggregates are shown in (Fig. 2). Coarse aggregates were used for slump testing, only.

\subsection{Compressive Strength Testing}

This investigation used test procedures outlined by ASTM C109/C109M-08 [30] to evaluate the effect of replacing Portland cement with different pozzolanic materials on

Table 1. Analysis of Cementitious Materials

\begin{tabular}{|c|c|c|c|c|c|}
\hline Determinate & Portland cement & Fly Ash & Pozzolan J & Pozzolan S1 & Pozzolan S2 \\
\hline $\mathrm{SiO}_{2}(\%)$ & 20 & 51.06 & 42.56 & 48.44 & 44.7 \\
\hline $\mathrm{Al}_{2} \mathrm{O}_{3}(\%)$ & 5.68 & 32.23 & 13.55 & 15.97 & 14.5 \\
\hline $\mathrm{CaO}(\%)$ & 64.94 & 4.18 & 9.75 & 8.53 & 9 \\
\hline $\mathrm{Fe}_{2} \mathrm{O}_{3}(\%)$ & 3.98 & 3.42 & 13.24 & 13.2 & 11.8 \\
\hline $\mathrm{MgO}(\%)$ & 0.7 & 1.06 & 11.15 & 7.89 & 7.8 \\
\hline $\mathrm{SO}_{3}(\%)$ & 2.81 & 0.42 & 0.35 & 0.1 & 0.15 \\
\hline Other $(\%)$ & 1.89 & 7.63 & 9.4 & 5.87 & 12.05 \\
\hline Water Requirement (\%) & - & 90 & 100 & 100 & 100 \\
\hline Free Water $(\%)$ & - & 0.1 & 0.1 & 0.1 & 0.1 \\
\hline Loss on Ignition (\%) & 1.16 & 0.81 & 2.56 & 1.26 & 1.5 \\
\hline Insoluble Residue (\%) & 0.32 & - & - & - & - \\
\hline Blaine Fineness $\left(\mathrm{m}^{2} / \mathrm{kg}\right)$ & 320 & 238 & 461 & 320 & 564 \\
\hline Density $\left(\mathrm{g} / \mathrm{cm}^{3}\right)$ & - & 2.2 & 2.86 & 2.8 & 2.8 \\
\hline
\end{tabular}


the compressive strength of test specimens (50 $\mathrm{mm}$ cubes). Cement and sand paste was selected instead of concrete mix to eliminate the variability exhibited by the presence of aggregate. In the test mixtures, mineral admixtures were used to replace $10,15,20,25,30$, and $40 \%$ of the mass of the Portland cement used in the control mixture. The results are presented in (Fig. 3) through (Fig. 6).

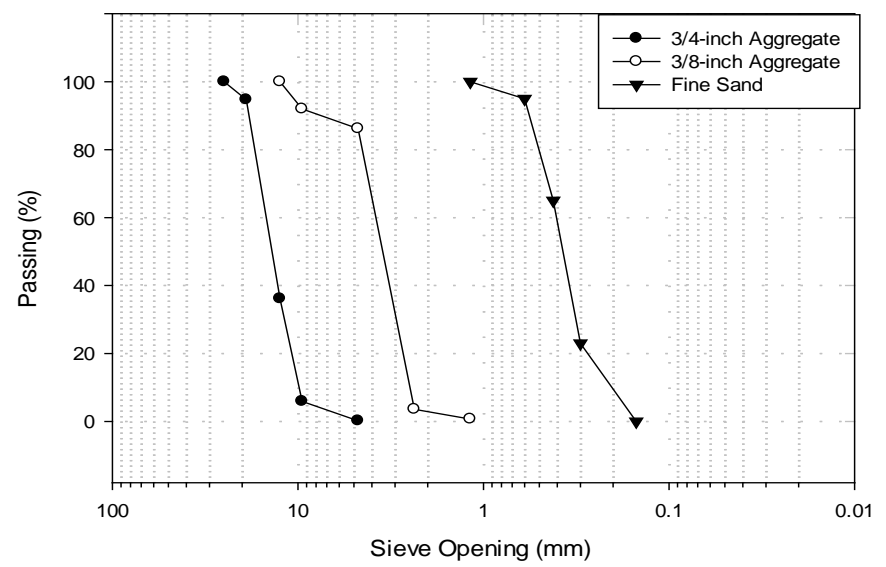

Fig. (2). Particle size distribution of aggregates.

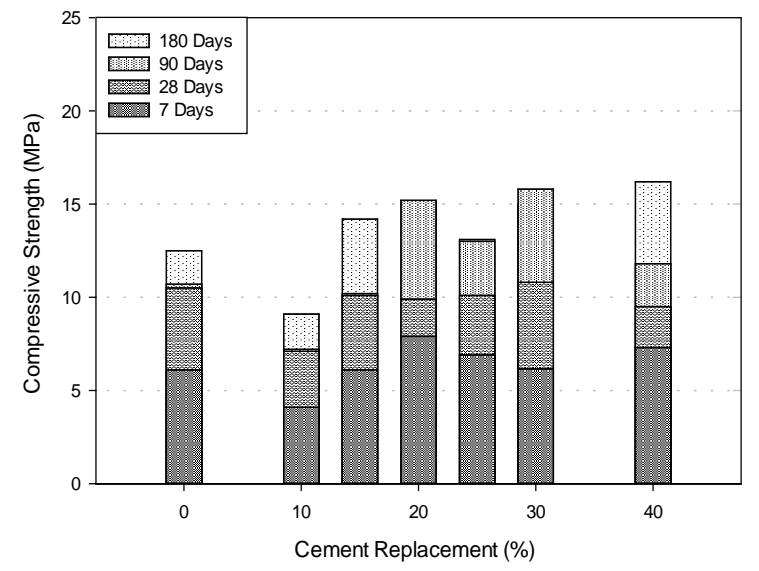

Fig. (3). Effect of cement replacement with fly ash on strength development.

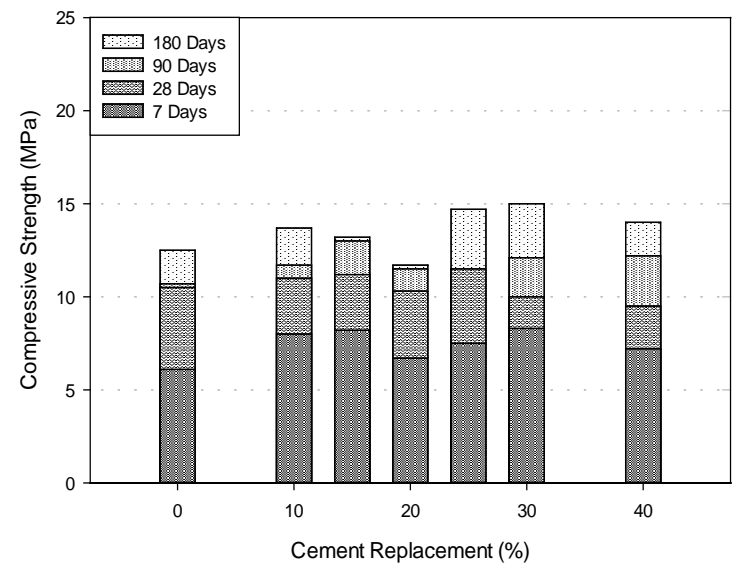

Fig. (4). Effect of cement replacement with Pozzolan J on strength development.

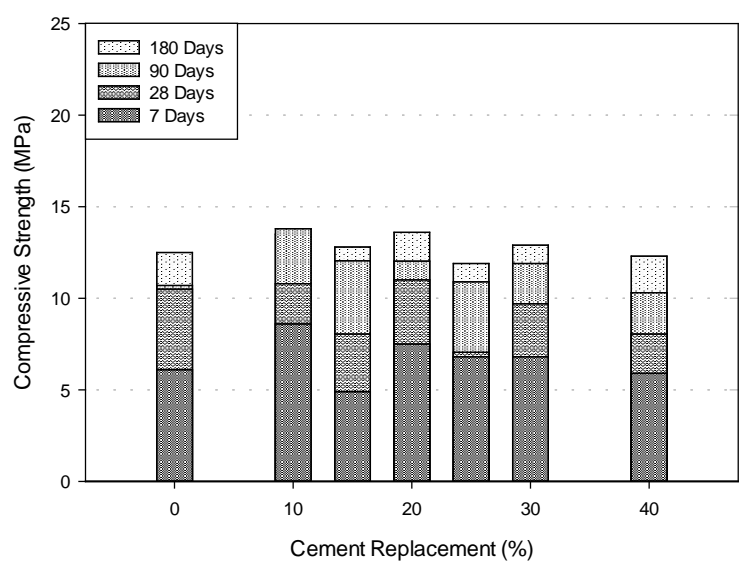

Fig. (5). Effect of cement replacement with Pozzolan S1 on strength development.

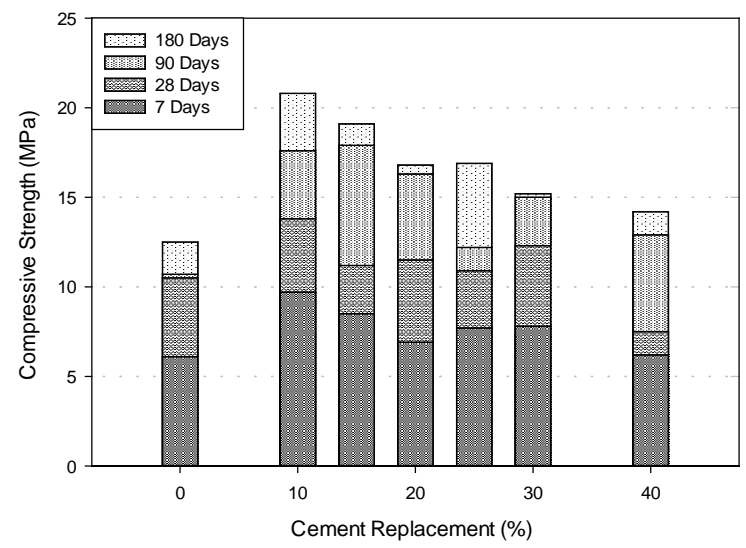

Fig. (6). Effect of cement replacement with Pozzolan $S 2$ on strength development.

The control mixture consisted of:

- $500 \mathrm{~g}$ of Portland cement.

- $1375 \mathrm{~g}$ of graded standard sand (ASTM C778-06 [31]).

- $242 \mathrm{~mL}$ of water.

Test mixtures consisted of:

- $450,425,400,375,350,300 \mathrm{~g}$ of Portland cement.

- $50,75,100,125,150,200 \mathrm{~g}$ of mineral admixtures.

- $1375 \mathrm{~g}$ of graded standard sand.

- $242 \mathrm{~mL}$ of water.

The test mortars contained 1 part cement to 2.75 parts graded aggregate (by mass) and a water-to-cement ratio equal to 0.485 (by mass).

Mixtures of the dry ingredients were prepared, water was added, and the specimens were mechanically mixed in accordance with ASTM C305-06 [32]. After mixing, cubes were poured in lifts and tamped as required by ASTM C109/109M-08 [30]. Immediately after molding, the specimens were placed in a moist room at $23.0 \pm 2.0{ }^{\circ} \mathrm{C}$. After 24 hours, the cubes were removed from the moist room, de- 
molded, and placed in water storage tanks until testing. The compressive strengths of two control specimens and two specimens of each test mixture were determined at 7, 28, 90, and 180 days. (Fig. 3) through (Fig. 6) show the results for the mixtures' compressive strength, which demonstrate that the natural pozzolans produce strengths similar to the fly ash.

Pozzolan S2 showed the best overall strength performance, with solid strength gain, even at 7 and 28 days. Many test mixes did not match the strength of the control mix at 7 or 28 days, but the strength of the majority of test mixes surpassed the control mix at 180 days. The distinguish performance of the $\mathrm{S} 2$ is maybe due to its purity.

\subsection{Strength Activity Index Testing}

The purpose of this phase of the study was to determine the strength activity index for concrete samples blended with fly ash, Pozzolan J, and Pozzolan S1. Specimens from a control mixture and a test mixture were prepared in accordance with ASTM C109/C109M-08 [30]. In the test mixture, 20\% of the mass of Portland cement used in the control mixture was replaced by the same mass of the test pozzolan. The batches of the test cube were produced in accordance with ASTM C311-00 [33]. The following formulas were used:

\section{Control Mixtures}

- $500 \mathrm{~g}$ of Portland cement.

- 1375 g of graded standard sand (Ottawa sand, ASTM C778-06 [31]).

- $242 \mathrm{~mL}$ of water.

Test Mixtures

- $400 \mathrm{~g}$ of Portland cement.

- $100 \mathrm{~g}$ of test sample (pozzolan).

- $1375 \mathrm{~g}$ of graded standard sand.

- $242 \mathrm{~mL}$ of water required for flow \pm 5 of control mixture.

After molding, the specimens were placed in a moist room at $23.0 \pm 2.0{ }^{\circ} \mathrm{C}$. After 24 hours, they were removed from the moist room and stored until testing in saturated lime water as specified in ASTM C109/C109M-08 [30]. Compressive strength was determined for two control specimens and two specimens of each test mixture at 7 and 28 days. Pozzolanic activity indexes were calculated as follows:

Strength Activity Index $(\mathrm{SAI})=(\mathrm{A} / \mathrm{B}) \times 100$, Strengthactivityindex-withPortlandcement. $=\mathrm{A} / \mathrm{Bxdwhere} \mathrm{A}=$ average compressive strength of test mix cubes, and $\mathrm{B}=$ average compressive strength of control mix cubes.

ASTM C618-00 [29] requires a minimum strength activity index of $75 \%$ at both 7 and 28 days. As shown in (Fig. 7), the Class F fly ash and Pozzolans J and S1 meet or exceed this requirement.

Also from (Fig. 7) can be concluded that at the early age of 7 days, the strength activity index of fly ash concrete due to packing effect is higher than due to pozzolanic reaction. Such detailed information could be very useful for the concrete technologist to select a suitable fly ash for use in concrete (Tangpagasit et al. 2005 [34]).

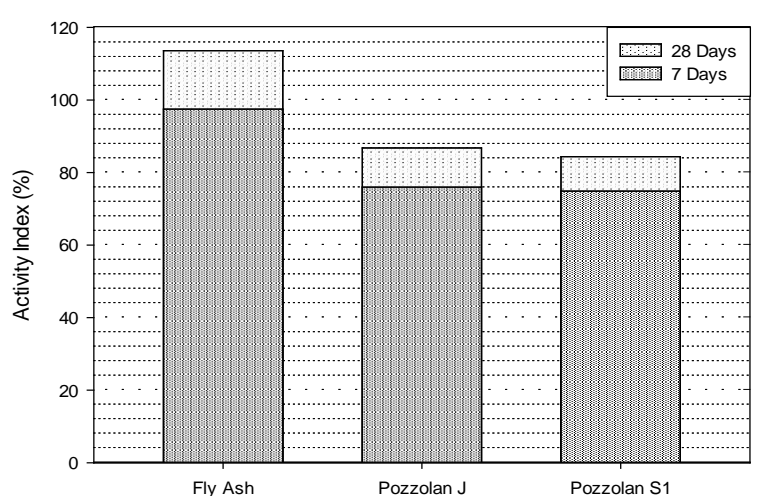

Fig. (7). Effect of various pozzolans on strength activity index.

\subsection{Alkali-Silica Reactivity Testing}

The purpose of this test series was to evaluate the effectiveness of the three test pozzolans in controlling ASR when used as a cement substitute. The investigation was carried out under laboratory conditions using procedures described in ASTM C1260-07 [35], Standard Test Method for Potential Alkali Reactivity of Aggregates (Mortar-Bar Method). This method enables the detection of the potential of a concrete mixture to undergo ASR, which produces potentially harmful expansion.

Four levels of cement replacement were investigated: 10, 20, 30 and 40\%. Basalt aggregates were crushed, sieved, washed, and re-graded as summarized in Section 2.1.2. The dry materials for the test mortar were prepared using a mixture of 1 part cement to 2.25 parts graded aggregate (by mass) to cast $25 \times 25 \times 286 \mathrm{~mm}$ bars. A water-to-cement ratio equal to 0.47 (by mass) was used. Each mold was placed in a moist cabinet or room immediately after it was filled. The specimens remained in the molds for $24 \pm 2$ hours, after which they were de-molded and placed in a storage container with enough tap water to totally immerse them for 24 hours at $80 \pm 2.0^{\circ} \mathrm{C}$.

The initial length of each test specimen was then measured using a length comparator in accordance with ASTM C490-08 [36], Standard Practice for Use of Apparatus for the Determination of Length Change of Hardened Cement Paste, Mortar, and Concrete. Subsequently, test specimens were stored in a container at $80 \pm 2.0^{\circ} \mathrm{C}$ with enough $\mathrm{NaOH}$ solution for the samples to be totally immersed. Expansion data were recorded periodically, with at least three intermediate readings between the start and finish of the test.

A 14-day expansion greater than $0.20 \%$ indicates a potentially reactive aggregate in the field, while a 14 day expansion smaller than $0.10 \%$ indicates a non-reactive aggregate. (Fig. 8 - Fig. 10) show the expansion test results. These results show that, although fly ash is slightly more effective than the natural pozzolans, both pozzolans significantly reduce the 14-day expansions and control ASR.

\subsection{Heat of Hydration Testing}

Heat of hydration is the quantity of heat (in joules per gram of unhydrated cement) that develops over the course of 
hydration at a given temperature. The most common method of determining the heat of hydration is described in ASTM C186-98 [37], Standard Test Method for Heat of Hydration of Hydraulic Cement. It is accomplished by measuring the heat of solutions of unhydrated and hydrated cement in a mixture of nitric and hydrofluoric acids. The difference between the two values represents the heat of hydration.

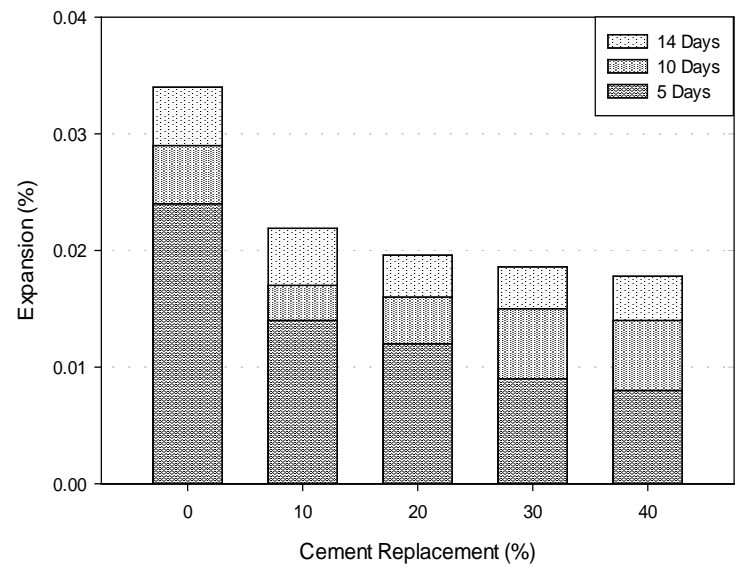

Fig. (8). Effect of cement replacement with fly ash on ASR expansion.

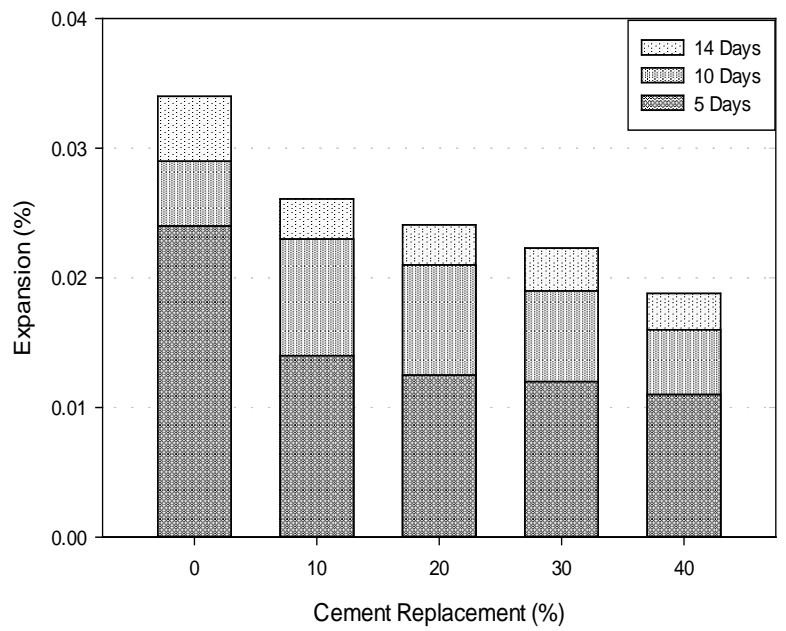

Fig. (9). Effect of cement replacement with Pozzolan J on ASR expansion.

This method was used to calculate the heat of hydration for one Portland cement control mixture and two test mixtures incorporating fly ash and Pozzolan S1. The results at curing durations of $1,3,7,14$, and 28 days are shown in (Fig. 11). This test series determined that the Pozzolan S1 mixture produced about $15 \%$ less heat of hydration than the fly ash mixture, where the fly ash mixture produced about $30 \%$ less heat of hydration than the control mixture.

\subsection{Effect of Pozzolan and Water-to-Cement Ratio on Slump}

Ten 2-inch cube specimens were prepared with varying amounts of Pozzolan S1 (between 0 and 30\%), and water-tocement $(\mathrm{W} / \mathrm{C})$ ratios varying between 0.456 and 0.5 . (Table 2) displays two slump testing mixture examples: a control mix and a $10 \%$ pozzolan mix. The slumps of nine specimens at 0,30 , and 45 minutes are shown in (Fig. 12). The results in (Fig. 12) show that increasing the amount of pozzolan generally increased the slump and workability of these specimens. In five specimens, the amount of pozzolan also varied between $10 \%$ and $30 \%$, but the $\mathrm{W} / \mathrm{C}$ ratios were decreased. As expected, reducing the $\mathrm{W} / \mathrm{C}$ ratio reduced the slump of the specimens.

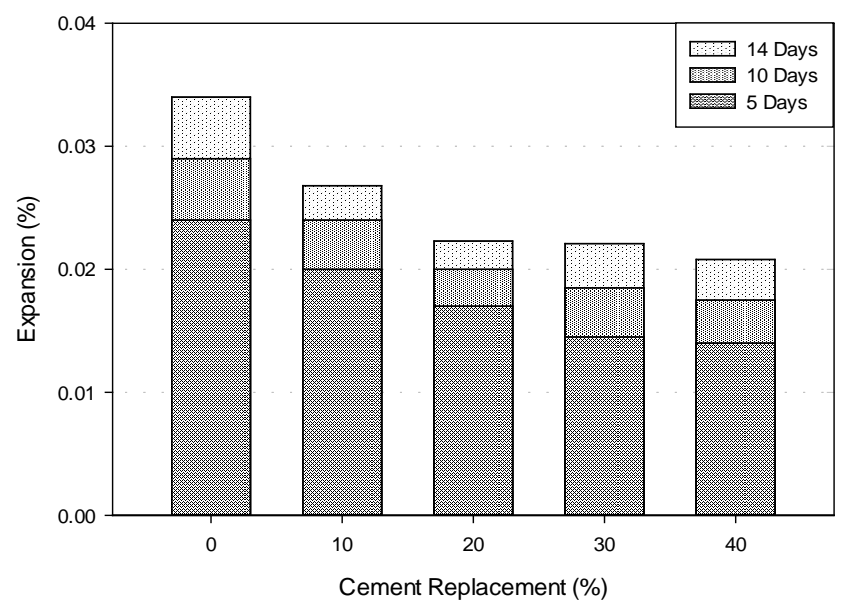

Fig. (10). Effect of cement replacement with Pozzolan S1 on ASR expansion.

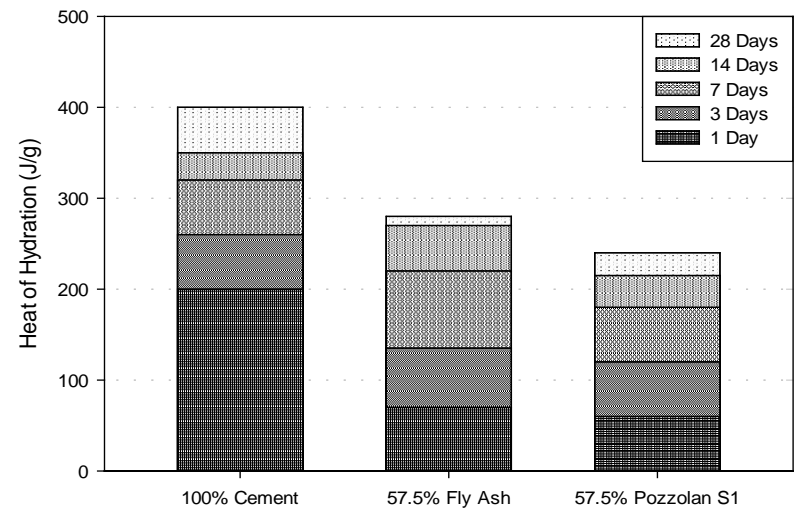

Fig. (11). Effect of various pozzolans on heat of hydration.

\subsection{Effect of Pozzolan and Water-to-Cement Ratio on Strength}

Specimens with varying amounts of Pozzolan S1 and $\mathrm{W} / \mathrm{C}$ ratios were tested in compression after 7 and 28 days to determine the effect of the pozzolan and $\mathrm{W} / \mathrm{C}$ ratio on the early compressive strength. The results of these tests are shown in (Fig. 13).

Activity indexes are calculated by dividing the specimen strength by the strength of a control specimen at the same age and multiplying by $100 \%$. The results in (Fig. 14) show that increasing the percentage of pozzolan generally decreases the activity index.

Three mixes were designed with $20 \%$ pozzolan, but each used pozzolan of a different fineness. As shown in (Fig. 15), 
the early compressive strengths of these specimens increased with increasing pozzolan fineness.

Table 2. Mixture for Control Specimens

\begin{tabular}{|c|c|c|c|}
\hline \multicolumn{4}{|c|}{ Test Mixes } \\
\hline \multicolumn{2}{|c|}{ Pozzolan replacement } & $0 \%$ & $10 \%$ \\
\hline \multicolumn{2}{|c|}{ Total Volume $\left(\mathrm{m}^{3}\right)$} & 0.03 & 0.03 \\
\hline \multicolumn{2}{|l|}{$W / c$} & 0.5 & 0.45 \\
\hline \multicolumn{4}{|c|}{ Ingredients } \\
\hline O.P.C. & $\mathrm{kg}$ & 10.5 & 8.4 \\
\hline Pozzolan & $"$ & 0 & 2.1 \\
\hline $3 / 4^{\prime \prime}$ & $"$ & 22.35 & 22.92 \\
\hline $3 / 8^{\prime \prime}$ & $"$ & 13.08 & 13.41 \\
\hline F. Sand & $"$ & 19.08 & 19.56 \\
\hline Free water & $\mathrm{L}$ & 5.25 & 4.719 \\
\hline Total water & $"$ & 5.652 & 5.139 \\
\hline $\operatorname{Pr}-150$ & $"$ & 0.063 & 0.063 \\
\hline \multicolumn{4}{|c|}{ Slump (mm) } \\
\hline \multicolumn{2}{|l|}{ Initial } & 170 & 50 \\
\hline \multicolumn{2}{|l|}{$30 \mathrm{~min}$} & 120 & - \\
\hline \multicolumn{2}{|l|}{$45 \mathrm{~min}$} & 105 & - \\
\hline \multicolumn{2}{|l|}{$60 \mathrm{~min}$} & 95 & - \\
\hline \multicolumn{4}{|c|}{ Temperature $\left({ }^{\circ} \mathrm{C}\right)$} \\
\hline \multicolumn{2}{|l|}{ Water } & 16 & 16 \\
\hline \multicolumn{2}{|l|}{ Ambient } & 15 & 16.8 \\
\hline \multicolumn{2}{|l|}{ Concrete(i) } & 20.5 & 20 \\
\hline \multicolumn{2}{|l|}{ Concrete(f) } & 19.5 & - \\
\hline
\end{tabular}

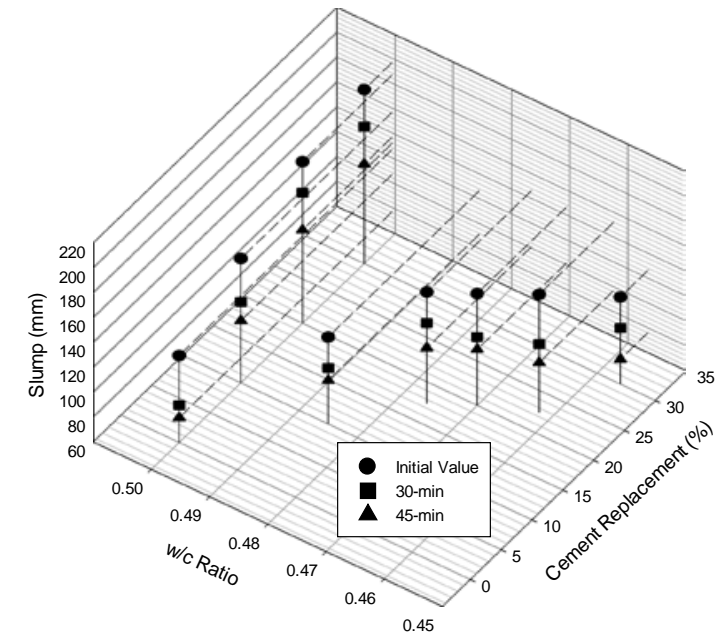

Fig. (12). Slump versus W/C-ratio and cement replacement with Pozzolan S1.

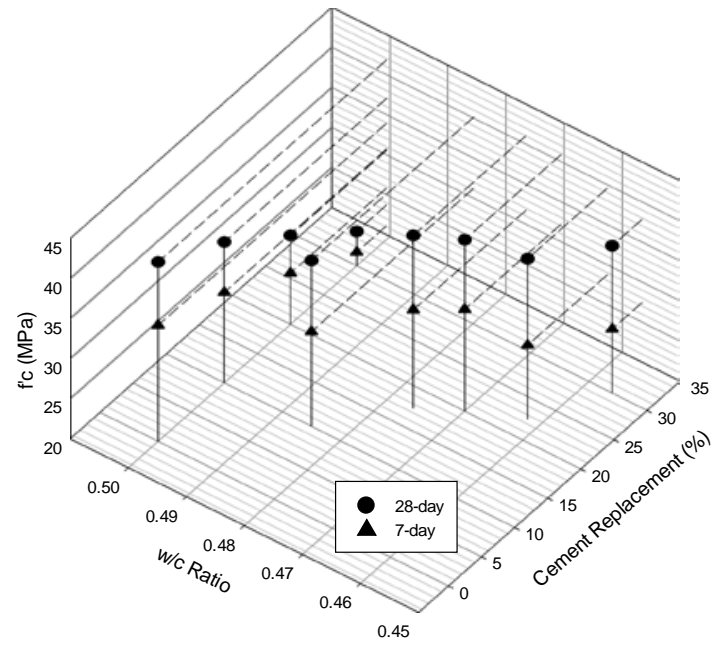

Fig. (13). Strength versus W/C-ratio and cement replacement with Pozzolan S1.

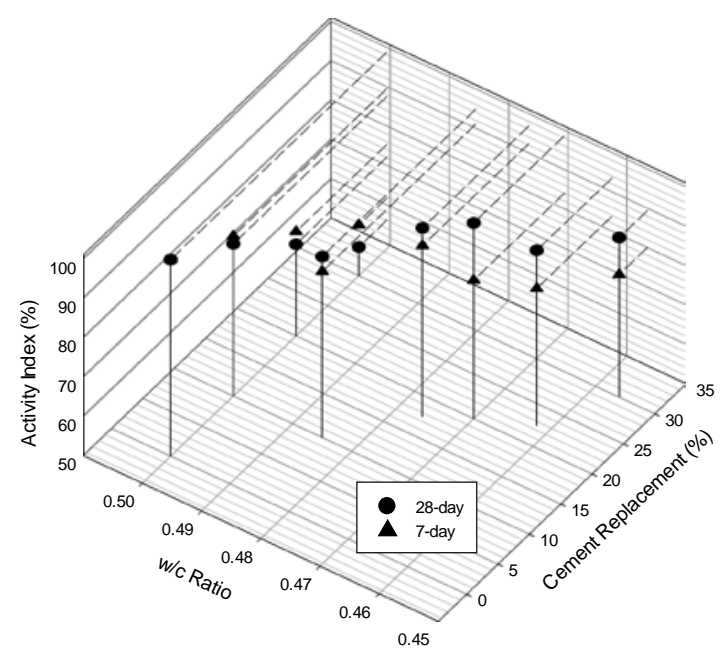

Fig. (14). Activity index versus $\mathrm{W} / \mathrm{C}$ and cement replacement with Pozzolan S1.

\section{COMPARISON OF POZZOLAN S1 WITH ASTM SPECIFICATIONS FOR FLY ASH AND SILICA FUME}

The properties of 20-micron fine natural Pozzolan S1 were investigated and compared with the ASTM specifications for fly ash and silica fume to determine the extent of their similarity. The following ASTM specifications were used as reference standards:

- ASTM C618-00 [29], Standard Specification for Coal Fly Ash and Raw or Calcined Natural Pozzolan for Use as a Mineral Admixture in Concrete. 
- ASTM C1240-00 [38], Standard Specification for use of Silica Fume as a Mineral Admixture in Hydraulic Cement Concrete Mortar and Grout.

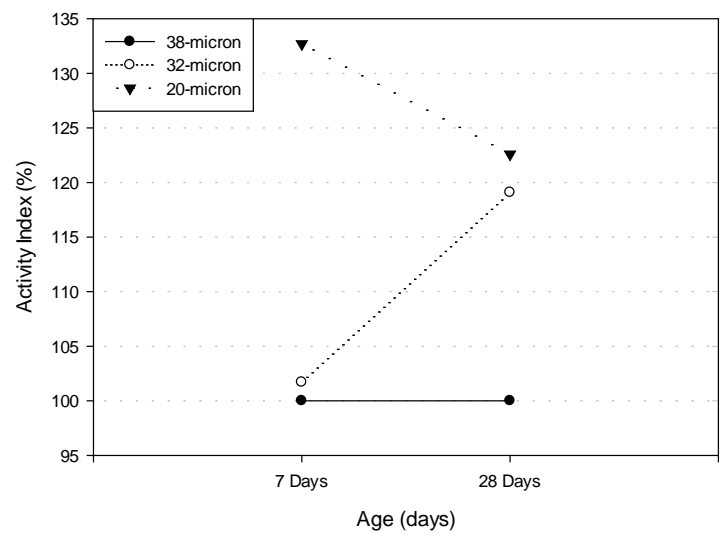

Fig. (15). Effect of Pozzolan S1 fineness on activity index $(20 \%$ replacement).

\subsection{Physical Tests}

The following physical tests were conducted on the pozzolan specimens:

- strength activity index (ASTM C311-00 [33]).

- density (ASTM C188-95 [39]).

- fineness per sieve analysis (ASTM C311-00 [33]).

- Blaine fineness (ASTM C204-00 [40]).

- increase in drying shrinkage (ASTM C157 [41]).

- expansion stability using autoclave (ASTM C157-08 [42]).

Two types of specimens were used: (1) a control specimen with $100 \%$ Portland cement and sand and (2) an activity specimen with $80 \%$ cement, $20 \%$ natural Pozzolan S1, and sand. The chemical composition and physical properties of the control specimen were used for comparison with the activity specimen. The results of the physical tests are shown in (Table $\mathbf{3}$ and Table 4).

Table 3. Strength Activity Index Results

\begin{tabular}{|c|c|c|}
\hline Property & $\begin{array}{c}\text { Control } \\
\text { specimen }\end{array}$ & $\begin{array}{c}\text { Activity } \\
\text { specimen }\end{array}$ \\
\hline \hline Shear Strength at 7 days $\left(\mathrm{N} / \mathrm{mm}^{2}\right)$ & 29.5 & 22.6 \\
\hline Strength Activity Index at 7 days, $\%$ & \multicolumn{2}{|c|}{76.6} \\
\hline Shear Strength $\left(\mathrm{N} / \mathrm{mm}^{2}\right)$ at 28 days & 36.0 & 28.0 \\
\hline Strength Activity Index at 28 days, $\%$ & & 77.8 \\
\hline
\end{tabular}

Table 4. Density, Fineness, Dry Shrinkage, and Volume Stability

\begin{tabular}{|c|c|c|}
\hline \multicolumn{2}{|c|}{ Physical Property } & Results \\
\hline \multicolumn{2}{|c|}{ Density } & $2.83 \mathrm{~g} / \mathrm{cm}^{3}$ \\
\hline \multirow{2}{*}{ Fineness } & Sieve analysis & $10.8 \%$ \\
\hline & Blaine & $359 \mathrm{~m}^{2} / \mathrm{kg}$ \\
\hline \multicolumn{2}{|c|}{ Increase in drying shrinkage after 28 days } & $-0.009 \% *$ \\
\hline \multicolumn{2}{|c|}{ Volume stability (autoclave expansion / contraction) } & $0.2 \%$ \\
\hline
\end{tabular}

* The ASTM standard specifies to add (-) sign if the dry shrinkage rate of contro specimens is greater than the tested specimens

\subsection{Chemical Tests}

Chemical analysis of the specimens was conducted to determine the effectiveness of the natural pozzolan in contributing to sulfate resistance. The results of the chemical analysis are given in (Table $\mathbf{5}$ and Table $\mathbf{6}$ ).

Table 5. Chemical Composition

\begin{tabular}{|c|c|c|}
\hline $\begin{array}{c}\text { Chemical } \\
\text { Composition, \% }\end{array}$ & $\begin{array}{c}\text { Control } \\
\text { Cement }\end{array}$ & $\begin{array}{c}\text { Natural } \\
\text { Pozzolan S1 }\end{array}$ \\
\hline \hline $\mathrm{SiO}_{2}$ & 19.26 & 48.44 \\
\hline $\mathrm{CaO}$ & 63.34 & 8.53 \\
\hline $\mathrm{Fe}_{2} \mathrm{O}_{3}$ & 3.6 & 13.3 \\
\hline $\mathrm{Al}_{2} \mathrm{O}_{3}$ & 5.35 & 15.97 \\
\hline $\mathrm{MgO}$ & 2.36 & 0.1 \\
\hline $\mathrm{SO}_{3}$ & 2.48 & 1.37 \\
\hline $\mathrm{K}_{2} \mathrm{O}$ & 0.51 & 0.012 \\
\hline $\mathrm{Cl}$ & 0.011 & \\
\hline
\end{tabular}

Table 6. Chemical Properties

\begin{tabular}{|c|c|c|}
\hline Property & Control Cement & Natural Pozzolan S1 \\
\hline \hline Loss on Ignition, $\%$ & 2.35 & 1.26 \\
\hline Moisture Content, \% & - & 0.34 \\
\hline PH & - & 9.0 \\
\hline Carbon Content, $\%$ & - & 0.33 \\
\hline Insoluble Residue, $\%$ & 0.74 & - \\
\hline
\end{tabular}

\subsection{Physical Analysis}

The physical properties of the natural pozzolan specimens are compared with the ASTM requirements for fly ash and silica fume in (Table 7). As shown in this table, the natural pozzolan specimens met the requirements for fly ash but 
Table 7. Comparison Between Pozzolan Physical Properties and ASTM Requirements

\begin{tabular}{|c|c|c|c|}
\hline Test & Results for Pozzolan S1 & $\begin{array}{c}\text { ASTM C618-00 Class N Pozzolan, } \\
\text { Class F and C Fly Ash [29] }\end{array}$ & $\begin{array}{c}\text { ASTM C1240-00 Silica } \\
\text { Fume [38] }\end{array}$ \\
\hline \hline Blaine Fineness $\left(\mathrm{m}^{2} / \mathrm{kg}\right)$ & 359 & - & 15 (min.) \\
\hline Pct. wt. remaining on 45-micron sieve & 10.8 & 75 (max.) & 10 (min.) \\
\hline Strength Activity Index at 7 days, $\%$ & 76.6 & 75 (min.) & 85 (min.) \\
\hline Strength Activity Index at 28 days, $\%$ & 77.8 & 0.8 (max.) & - \\
\hline Autoclave expansion/contraction, $\%$ & 0.02 & 0.03 (max.) & - \\
\hline Pct. Drying Shrinkage at 28 days & -0.009 & - \\
\hline
\end{tabular}

not for silica fume. The fineness values were less than $34 \%$, and the strength activity indexes were greater than $75 \%$. Their volume stabilities were less than $0.8 \%$, and the increase in drying shrinkage at 28 days was less than $0.03 \%$. While the natural pozzolan met the silica fume requirements for Blaine fineness and the percentage remaining on the 45 micron sieve, it is significant that it did not meet the 7-day strength activity index of $85 \%$. The reason may be attributed to the Silica fume ultrafine material with spherical particles less than $1 \mu \mathrm{m}$ in diameter being much less than the size of natural pozzolan.

\subsection{Chemical Analysis}

The chemical test results for the natural pozzolan specimen were compared with the ASTM requirements, as shown in (Table 8). The natural pozzolan specimens met all requirements for fly ash but did not meet the $85 \%$ silicon dioxide requirement for silica fume. It is worth noting that the ASTM specification for class $F$ fly ash requires the sum of $\mathrm{Fe} 2 \mathrm{O} 3, \mathrm{~A} 12 \mathrm{O} 3$, and $\mathrm{SiO} 2$ to be at least $70 \%$. It also specifies SO3 less than $5 \%$, moisture content less than $3 \%$, and loss on ignition less than $6 \%$. Therefore, natural pozzolan behaves more as a fly ash than a silica fume.

\section{CONCLUDING REMARKS}

From the previous results we can conclude that:

- At the early ages, the strength activity index of fly ash due to packing effect is higher than due to pozzolanic reaction.
- Pozzolan S1 can provide a satisfactory substitute for fly ash and other natural pozzolans as tested against ASTM C618-00 [29]. It was clearly found to be effective in controlling ASR. It also produces about $15 \%$ less heat of hydration than Class F fly ash, whereas Class F fly ash produces about 30\% less heat of hydration than Portland cement only.

- Pozzolan specimens ground to a size of 20 microns meet the chemical and physical requirements for fly ash. The fineness values were less than $34 \%$, and the strength activity indexes at 7 and 28 days were greater than $75 \%$. Volume stabilities were less than $0.8 \%$, and the increase in drying shrinkage at 28 days was less than $0.03 \%$. The percentage of total iron oxide, aluminum oxide, and silicon dioxide was greater than $70 \%$. The percentage of sulfur trioxide was less than $5 \%$. Moisture content was less that $3 \%$. Loss on ignition was less than $6 \%$.

- The chemical and physical properties of Pozzolan S1 are comparable to fly ash, and the one can be substituted for the other.

It should be mentioned that Pozzolan S1 did not meet the ASTM C1240-00 [38] chemical and physical requirements for silica fume. Its strength activity index at 7 days was less than $85 \%$, and the percentage of silicon dioxide was not met. However, it met the requirements for the percentage remaining on the 45 micron sieve at greater than $10 \%$, moisture content less than $3 \%$, loss on ignition less than $6 \%$, and Blaine fineness greater than $15 \mathrm{~m} 2 / \mathrm{kg}$.

Table 8. Comparison Between Pozzolan Properties and ASTM Requirements

\begin{tabular}{|c|c|c|c|c|c|}
\hline \multirow{3}{*}{ Test } & \multirow{3}{*}{ Results for Pozzolan S1 } & \multicolumn{4}{|c|}{ ASTM C618-00 [29] } \\
\hline & & \multirow{2}{*}{ Natural Pozzolan Class $\mathbf{N}$} & \multicolumn{2}{|c|}{ Fly ash } & \multirow[t]{2}{*}{ Silica fume } \\
\hline & & & Class F & Class C & \\
\hline $\mathrm{Fe}_{2} \mathrm{O}_{3}+\mathrm{Al}_{2} \mathrm{O}_{3}+\mathrm{SiO}_{2}(\%)$ & 77.61 & 70 (min.) & 70 (min.) & 50 (min.) & - \\
\hline $\mathrm{SO}_{3}(\%)$ & 0.34 & 4 (max.) & 5 (max.) & 5 (max.) & - \\
\hline Moisture content (\%) & 0.1 & 3 (max.) & 3 (max.) & 3 (max.) & - \\
\hline Loss on ignition (\%) & 1.26 & 10 (max.) & 6 (max.) & 6 (max.) & 6 (max.) \\
\hline $\mathrm{SiO}_{2}(\%)$ & 48.44 & - & - & - & 85 (min.) \\
\hline
\end{tabular}


Based on the above findings, it is concluded that Pozzolan S1 is not a suitable replacement for ASTM C1240-00 [38] silica fume despite meeting the requirements for fineness, moisture content, and loss on ignition.

\section{CONFLICT OF INTEREST}

The author(s) confirm that this article content has no conflicts of interest.

\section{ACKNOWLEDGEMENT}

The authors would like to acknowledge the assistance of Kevin O'Connor, a civil engineering graduate student at the University of Illinois, Urbana-Champaign. The authors are also grateful to Miltiadis Chronopoulos, Research Associate at the National Technical University of Athens, and Adamantia Athanasopoulou, Programme Leader, Faculty of Engineering, Metropolitan College, Athens, Greece for their helpful discussions and suggestions.

\section{REFERENCES}

[1] B. B. Sabir, S. Wild, and J. Bai, "Metakaolin and calcined clays as pozzolans for concrete: a review", Cement and Concrete Composites, vol. 23, no. 6, pp. 441-454, 2001.

[2] H. Binici, O. Aksogan, I. H. Cagatay, M. Tokyay, and E. Emsen, "The effect of particle size distribution on the properties of blended cements incorporating GGBFS and natural pozzolan (NP)", Powder Technology, vol. 177, no. 3, pp. 140-147, 2007.

[3] A. Çavdar, and S. Yetgin, "Availability of tuffs from northeast of Turkey as natural pozzolan on cement, some chemical and mechanical relationships", Construction and Building Materials, vol. 21, no. 12, pp. 2066-2071, 2007.

[4] S. K. Antiohos, A. Papageorgiou, V. G. Papadakis, and S. Tsimas, "Influence of quicklime addition on the mechanical properties and hydration degree of blended cements containing different fly ashes", Construction and Building Materials, vol. 22, no. 6, pp. 1191-1200, 2008.

[5] E. Badogiannis, and S. Tsivilis, "Exploitation of poor Greek kaolins: Durability of metakaolin concrete", Cement and Concrete Composites, vol. 31, no. 2, pp. 128-133, 2009.

[6] G. Mertens, R. Snellings, K. Van Balen, B. Bicer-Simsir, P. Verlooy, and J. Elsen, "Pozzolanic reactions of common natural zeolites with lime and parameters affecting their reactivity", Cement and Concrete Research, vol. 39, no. 3, pp. 233-240, 2009.

[7] A. R. Pourkhorshidi, M. Najimi, T. Parhizkar, F. Jafarpour, and B. Hillemeier, "Applicability of the standard specifications of ASTM C618 for evaluation of natural pozzolans", Cement and Concrete Composites, vol. 32, no. 10, pp. 794-800, 2010.

[8] K. M. A. Hossain, and L. Mol, "Some engineering properties of stabilized clayey soils incorporating natural pozzolans and industrial wastes", Construction and Building Materials, vol. 25, no. 8, pp. 3495-3501, 2011.

[9] Y. Senhadji, G. Escadeillas, H. Khelafi, M. Mouli, and A. S. Benosman, "Evaluation of natural pozzolan for use as supplementary cementitious material", European Journal of Environmental and Civil Engineering, vol. 16, no. 1, pp. 77-96, 2012.

[10] M. Valipour, F. Pargar, M. Shekarchi, and S. Khani, "Comparing a natural pozzolan, zeolite, to metakaolin and silica fume in terms of their effect on the durability characteristics of concrete: A laboratory study", Construction and Building Materials, vol. 41, pp. 879888,2013

[11] P. Gibbons, "Pozzolans for Lime Mortars", The Conservation and Repair of Ecclesiastical Buildings, 1997. [Online] available: $\mathrm{http}: / /$ www.buildingconservation.com/articles/pozzo/pozzo.htm.

[12] S. Tsimas, and A. Moutsatsou-Tsima, "High-calcium fly ash as the fourth constituent in concrete: Problems, solutions and perspectives", Cement and Concrete Composites, vol. 27, no. 2, pp. 231237,2005

[13] A. Moropoulou, P. Maravelaki-Kalaitzaki, M. Borboudakis, A. Bakolas, P. Michailidis, and M. Chronopoulos, "Historic mortars technologies in Crete and guidelines for compatible restoration mortars, PACT: Journal of the European Study Group on Physical,
Chemical, Biological and Mathematical Techniques Applied to Archaeology, vol. 55, pp. 55-72, 1998.

[14] A. Moropoulou, A. Bakolas, and E. Aggelakopoulou, "Evaluation of pozzolanic activity of natural and artificial pozzolans by thermal analysis, Thermochimica Acta, vol. 420, no. 1-2, pp. 135-140, 2004.

[15] A. Moropoulou, A. Bakolas, and S. Anagnostopoulou, "Composite materials in ancient structures", Cement and Concrete Composites, vol. 27, no. 2, pp. 295-300, 2005.

[16] P. G. Asteris, A. D. Tzamtzis, P. P. Vouthouni, and D. S. Sophianopoulos, "Earthquake Resistant Design and Rehabilitation of Masonry Historical Structures", Practice Periodical on Structural Design and Construction, American Society of Civil Engineers (ASCE), vol. 10, no. 1, pp. 49-55, 2005.

[17] L. Dolar-Mantuani, Handbook of Concrete Aggregates, A Petrographic and Technological Evaluation, Noyes Data Corporation, United States, pp. 79-125, 1984.

[18] T. E. Stanton, "Expansion of concrete through reaction between cement and aggregate", Proceedings of the American Society of Civil Engineers, vol. 66, no. 10, pp. 1781-1811, 1940

[19] D. W. Hobbs, Alkali-Silica Reaction in Concrete, Thomas Telford, London, 1988.

[20] F. Björkand, and C. A. Eriksson, "Measurement of alkalinity in concrete by a simple procedure, to investigate transport of alkaline material from the concrete slab to a self-levelling screed", Construction and Building Materials, vol. 16, no. 8, pp. 535-542, 2002.

[21] ASTM Standard C150-09, Standard Specification for Portland Cement, ASTM International, West Conshohocken, PA, 2009.

[22] R. O. Lane, and J. F. Best, "Properties and use of fly ash in Portland cement concrete", Concrete International, vol. 4, no. 7, pp. 81-92, 1982.

[23] H. Wang, and J. E. Gillott, "Effect of Three Zeolite-containing Natural Pozzolanic Materials on Alkali-Silica Reaction", Cement, Concrete, and Aggregates, vol. 15, no. 1, pp. 24-30, 1993.

[24] M. D. A. Thomas, and F. A. Innis, "Use of the Accelerated MortarBar Test for Evaluating the Efficacy of Mineral Admixtures for Controlling Expansion Due to Alkali-Silica Reaction", Cement, Concrete and Aggregates, vol. 21, no. 2, pp. 157-164, 1999.

[25] J. H. Yeon, S. Choi, and M. C. Won, "In situ measurement of coefficient of thermal expansion in hardening concrete and its effect on thermal stress development", Construction and Building Materials, vol. 38, pp. 306-315, 2013.

[26] G. De Schutter, "Finite element simulation of thermal cracking in massive hardening concrete elements using degree of hydration based material laws", Computers and Structures, vol. 80, no. 2730, pp. 2035-2042, 2002.

[27] M. Tokyay, T. Delibaş, and I. O. Yaman, "Heat of Hydration of GGBFS and Natural Pozzolan Incorporated Cements", Cement \& Concrete World, vol. 17, no. 95, p. 72, 2012.

[28] M. Nili, and A. M. Salehi, "Assessing the effectiveness of pozzolans in massive high-strength concrete", Construction and Building Materials, vol. 24, no. 11, pp. 2108-2116, 2010.

[29] ASTM Standard C618-00, Specification for Coal Fly Ash and Raw or Calcined Natural Pozzolan for Use as a Mineral Admixture in Portland Cement Concrete, ASTM International, West Conshohocken, PA, 2000.

[30] ASTM Standard C109/C109M-08, Test Method for Compressive Strength of Hydraulic Cement Mortars (Using 2-in. or 50-mm Cube Specimens), ASTM International, West Conshohocken, PA, 2008.

[31] ASTM Standard C778-06, Standard Specification for Standard Sand, ASTM International, West Conshohocken, PA, 2006.

[32] ASTM Standard C305-06, Standard Practice for Mechanical Mixing of Hydraulic Cement Pastes and Mortars of Plastic Consistency, ASTM International, West Conshohocken, PA, 2006.

[33] ASTM Standard C311-00, Standard Test Methods for Sampling and Testing Fly Ash or Natural Pozzolans for Use in PortlandCement Concrete, ASTM International, West Conshohocken, PA, 2000.

[34] J. Tangpagasit, R. Cheerarot, C. Jaturapitakkul, and K. Kiattikomol, "Packing effect and pozzolanic reaction of fly ash in mortar", Cement and Concrete Research, vol. 35, no. 6, pp. 1145-1151, 2005.

[35] ASTM Standard C1260-07, Standard Test Method for Potential Alkali Reactivity of Aggregates (Mortar-Bar Method), ASTM International, West Conshohocken, PA, 2007. 
[36] ASTM Standard C490-08, Standard Practice for Use of Apparatus for the Determination of Length Change of Hardened Cement Paste, Mortar, and Concrete, ASTM International, West Conshohocken, PA, 2008.

[37] ASTM Standard C186-98, Standard Test Method for Heat of Hydration of Hydraulic Cement, ASTM International, West Conshohocken, PA, 1998.

[38] ASTM Standard C1240-00, Standard Specification for Silica Fume Used in Cementitious Mixtures, ASTM International, West Conshohocken, PA, 2000.
[39] ASTM Standard C188-95, Standard Test Method for Density of Hydraulic Cement, ASTM International, West Conshohocken, PA, 1995.

[40] ASTM Standard C204-00, Standard Test Methods for Fineness of Hydraulic Cement by Air-Permeability Apparatus, ASTM International, West Conshohocken, PA, 2000.

[41] ASTM Standard C157, "Standard test method for length change of hardened hydraulic-cement mortar and concrete", Annual Book of ASTM Standards, 04.02 Concrete and Concrete Aggregates, 1997.

[42] ASTM Standard C157-08, Standard Test Method for Length Change of Hardened Hydraulic-Cement Mortar and Concrete, ASTM International, West Conshohocken, PA, 2008.

Received: May 05, 2013

Revised: June 14, 2013

Accepted: June 18, 2013

(C) Al-Chaar et al.; Licensee Bentham Open.

This is an open access article licensed under the terms of the Creative Commons Attribution Non-Commercial License (http:/creativecommons.org/licenses/by-nc/3.0/) which permits unrestricted, non-commercial use, distribution and reproduction in any medium, provided the work is properly cited. 